\title{
ANALISIS KEUNTUNGAN PEDAGANG PENGUMPUL "KELAPA KUAH" DI DESA TEWASEN KECAMATAN AMURANG BARAT
}

\author{
Exaudia Enggelina Rempowatu \\ Paulus Adrian Pangemanan \\ Grace Adonia Josefina Rumagit
}

\begin{abstract}
The research aims to calculate the profit of coconut collector "Kelapa Kuah" in Tewasen Village, West Amurang Sub-district. This research was conducted for 3 months from April to June 2018. The method used in this study was the survey method with the technique of direct interviewing with coconut collector. The research result showed that the profit of the coconut collecting trader was $R p .16 .861 .169$ and $R / C$ ratio was 1.18 which meant that the business of coconut collecting trader was economically profitable and could be maintained. *JNKD*
\end{abstract}

Keywords : profit analysis, collecting trader, "Kelapa Kuah", Tewasen Village, West Amurang Sub-district

\begin{abstract}
ABSTRAK
Penelitian ini bertujuan untuk menghitung keuntungan pedagang pengumpul "Kelapa Kuah" di Desa Tewasen, Kecamatan Amurang Barat. Penelitian ini dilakukan selama 3 bulan dari bulan April sampai Juni 2018. Metode yang digunakan dalam penelitian ini adalah metode survei dengan teknik wawancara langsung kepada seorang pedagang pengumpul. Hasil penelitian menunjukkan bahwa keuntungan pedagang pengumpul sebesar Rp.16.861.169 dan $\mathrm{R} / \mathrm{C}$ ratio 1,18 yang berarti usaha pedagang pengumpul di Desa Tewasen menguntungkan secara ekonomi dan dapat dipertahankan
\end{abstract}

Kata kunci : analisis keuntungan, pedagang pengumpul, "Kelapa Kuah", Desa Tewasen, Kecamatan Amurang Barat

\section{PENDAHULUAN}

\section{Latar Belakang}

Sektor pertanian merupakan sektor strategis dalam pembangunan nasional. Peran sektor pertanian dalam memacu perekonomian dapat dilihat lebih luas terutama dalam konteks mendistribusikan hasil-hasil pembangunan kepada masyarakat wilayah pedesaan. Sektor pertanian dituntut untuk berperan dalam perekonomian nasional melalui pembentukan produk domestik bruto, perolehan devisa, penyediaan pangan dan bahan baku industri, pengentasan kemiskinan, penyediaan lapangan kerja, dan peningkatan pendapatan masyarakat (Rorenkeu dalam Dongi 2014).

Indonesia merupakan negara tropis berbentuk kepulauan yang merupakan salah satu negara produsen kelapa di dunia. Saat ini, Indonesia memiliki luas perkebunan kelapa 
terbesar di dunia yakni 3,585 juta Ha, sebagian besar merupakan perkebunan rakyat $(98,98 \%)$ sisanya perkebunan milik negara $(0,11 \%)$ dan perkebunan swasta $(0,92 \%)$ dengan potensi total produksi sekitar 2,920 ton per tahun (Ditjenbun, 2017). Hal ini disebabkan karena kelapa umumnya tumbuh di kawasan pantai, dan bagi masyarakat Indonesia kelapa merupakan sumber pendapatan utama bagi petani karena kelapa memiliki berbagai manfaat bagi kehidupan manusia mulai dari buah, daun, batang sampai ke akarnya.

Biasanya kelapa diolah menjadi beberapa produk olahan kelapa seperti tepung kelapa, minyak goreng, virgin coconut oil, santan untuk masak dan masih banyak lagi bentuk olahan dari kelapa. Sebagai produsen kelapa terbesar di dunia, Indonesia menjadi ajang bisnis raksasa mulai dari pengadaan sarana produksi (bibit, pupuk, pestisida), proses produksi, pengolahan produk kelapa (turunan dari daging, tempurung, sabut, kayu, lidi, dan nira), dan aktivitas penunjangnya seperti : keuangan, irigasi, transportasi, dan perdagangan (Departemen Pertanian, 2007).

Sulawesi Utara merupakan salah satu daerah sentra produksi kelapa di Indonesia, yang memiliki luas areal tanaman kelapa yang besar, sehingga daerah ini disebut daerah Nyiur Melambai. Sepanjang tahun 2015-2017 luas areal perkebunan kelapa Minahasa Selatan mencapai $45.751 \mathrm{Ha}$ dengan jumlah produksi sebesar 41.532 ton dan jumlah produktivitas sebesar $1.106 \mathrm{Kg} / \mathrm{Ha}$ sedangkan jumlah petani di Minahasa Selatan sebanyak 27.165 KK (Ditjenbun, 2017).

Tabel 1 menunjukkan luas areal dan produksi tanaman kelapa di Kabupaten Minahasa Selatan. Kecamatan Tenga yang memiliki luas areal tanaman kelapa terbesar, diikuti Kecamatan Amurang Barat diurutan kedua, sementara luas areal terkecil pada Kecamatan Motoling. Sedangkan untuk produksi kelapa, terdapat tiga kecamatan yang memproduksi kelapa terbanyak di kabupaten Minahasa Selatan yaitu Kecamatan Tenga, Sinonsayang, dan Amurang Barat. Pada Tahun 2017, populasi tanaman kelapa di kecamatan ini sebanyak 569.618 pohon. Luas lahan perkebunan terbesar di kecamatan Amurang Barat adalah tanaman kelapa karena komoditas ini dianggap mempunyai nilai ekonomi yang tinggi.

Tabel 1. Luas Areal dan Produksi Kelapa di Kabupaten Minahasa Selatan Tahun 2016

\begin{tabular}{|c|c|c|c|}
\hline No & Kecamatan & $\begin{array}{c}\text { Luas Areal } \\
\text { (Ha) }\end{array}$ & $\begin{array}{c}\text { Jumlah } \\
\text { Produksi (Ton) }\end{array}$ \\
\hline 1. & Modoinding & - & - \\
\hline 2. & Tompaso Baru & 544.50 & 248.44 \\
\hline 3. & Maesaan & 1,021 & 260.44 \\
\hline 4. & Ranoyapo & 2,993 & $1,850.88$ \\
\hline 5. & Motoling & 930 & 538.41 \\
\hline 6. & Kumelembuai & 1,034 & 579.10 \\
\hline 7. & Motoling Barat & 1,190 & 669.53 \\
\hline 8. & Motoling Timur & 1,446 & 912.15 \\
\hline 9. & Sinonsayang & $6,620.50$ & $3,999.25$ \\
\hline 10. & Tenga & $7,948.86$ & $4,559.10$ \\
\hline 11. & Amurang & 2,739 & $1,326.17$ \\
\hline 12. & Amurang Barat & $6,814.70$ & $3,125.50$ \\
\hline 13. & Amurang Timur & 4,620 & $2,159.16$ \\
\hline 14. & Tareran & 1,183 & 735.24 \\
\hline 15. & Sulta & 1,470 & 867.72 \\
\hline 16. & Tumpaan & 1,902 & 855.14 \\
\hline 17. & Tatapaan & 3,360 & $1,46.35$ \\
\hline & Total & 28 & 100 \\
\hline
\end{tabular}

Sumber : Badan Pusat Statistik Minahasa Selatan, 2018

Tabel 2 menunjukkan jumlah penjualan "Kelapa Kuah" dari pedagang pengumpul pada perusahaan tepung kelapa pada tahun 2017 di Kecamatan Amurang Barat. Pedagang pangumpul dari desa Tewasen merupakan pedagang yang paling banyak menjual "Kelapa Kuah" sedangkan yang paling sedikit dari pedagang pangumpul Desa Elusan. Terdapat dua desa di Kecamatan Amurang Barat yang tidak memiliki pedagang pengumpul "Kelapa Kuah" sehingga tidak terdapat dalam daftar dari perusahaan tepung kelapa, yaitu desa Rumoong Bawah dan Desa Wakan.

Tabel 2. Pembelian "Kelapa Kuah" Pada Pedagang Pengumpul Kelapa di Kecamatan Amurang Barat Tahun 2017

\begin{tabular}{llrr}
\hline No & Desa & Pembelian (Ton) & Persentase (\%) \\
\hline 1. & Kawangkoan Bawah & 335 & 28.53 \\
2. & Pondos & 19 & 1.61 \\
3. & Elusan & 7 & 0.59 \\
4. & Tewasen & 475 & 40.45 \\
5. & Teep & 128 & 10.90 \\
6. & Kapitu & 210 & 17.88 \\
7. & Rumoong Bawah & - & 0 \\
8. & Wakan & - & 0 \\
\hline \multicolumn{4}{c}{ Total } \\
\hline \multicolumn{2}{l}{ Sumber : Perusahaan Tepung Kelapa Trimustika Coco Minaesa }
\end{tabular}


"Kelapa Kuah" merupakan istilah lokal dari penduduk Desa Tewasen yaitu kelapa tanpa sabut dalam bentuk butir yang biasa dijual petani kepada pedagang pengumpul. Desa Tewasen merupakan desa yang sebagian besar masyarakatnya memiliki lahan yang ditanami kelapa serta mengandalkan tanaman ini untuk memperoleh pendapatan dalam membiayai hidupnya. Sebagian besar petani kelapa menjual masih dalam bentuk "Kelapa Kuah" kepada pedagang pengumpul desa. Pedagang pengumpul membeli langsung kelapa butir kepada petani yang dibawa langsung oleh petani ke tempat penampungan.

Pedagang pengumpul dari desa-desa di Kecamatan Amurang Barat telah lama menjadi supplier pada perusahaan tepung kelapa PT. Tri Mustika Cocomiaesa dan harga “Kelapa Kuah' ditentukan oleh perusahaan. Kemudian, berdasarkan harga beli dari perusahaan maka pedagang pengumpul yang menetapkan harga beli dari petani. Pedagang pengumpul desa telah lama menekuni usaha ini, karena usaha ini sangat membantu penghasilannya. Selama menjalankan usahanya, pedagang pengumpul di Desa Tewasen hanya memperkirakan keuntungan usahanya tetapi tidak menghitung dengan pasti keuntungan yang di dapat ketika menjalankan usaha ini. Dengan demikian menjadi penting untuk menganalisis keuntungan pedagang pengumpul "Kelapa Kuah", karena tujuan usahanya untuk memperoleh keuntungan semaksimal mungkin.

\section{Peranan Komoditas Kelapa Dalam Perekonomian}

Kelapa adalah tanaman dengan banyak manfaat. Tanaman ini dapat menyediakan makanan, minuman, pakaian dan tempat tinggal, juga sebagai sumber pendapatan produk-produk olahannya (Foale dalam Samsul 2017)

Secara tradisional, penggunaan produk kelapa adalah untuk konsumsi segar, dibuat kopra atau minyak kelapa. Akan tetapi, seiring dengan perkembangan pasar dan dukungan teknologi, maka permintaan berbagai produk turunan kelapa semakin meningkat seperti dalam bentuk kelapa, serat sabut, arang tempurung dan arang aktif. Dalam sepuluh tahun terakhir, penggunaan tepung kelapa meningkat dengan laju 21.9 persen/tahun. Sebaliknya, penggunaan domestik minyak kelapa cenderung berkurang. Penggunaan minyak kelapa di dalam negeri yang semakin berkurang diduga terkait dengan perubahan preferensi konsumen yang lebih menyukai penggunaan minyak kelapa sawit karena harganya lebih murah (Dewi, 2011).

Pada tahun 2005 penggunaan domestik kopra mencapai 1.62 juta ton. Sedangkan CCO sebesar 320 ribu ton. Penggunaan domestik kelapa butiran pada tahun yang sama mencapai 16.5 juta ton. Pada tepung kelapa dan serat sabut, penggunaan dalam negeri justru berasal dari produk impor karena produksi dalam negeri seluruhnya diekspor (Dewi, 2011).

Areal tanaman kelapa di Indonesia merupakan yang terluas di dunia dengan pangsa $31,2 \%$ dari total luas areal kelapa dunia. Peringkat kedua diduduki Filipina (pangsa 25,8\%), disusul India (pangsa 16,0\%), Srilangka (pangsa 3,7\%), dan Thailand (pangsa $3,1 \%$ ). Namun demikian, dari segi produksi ternyata Indonesia hanya menduduki posisi kedua setelah Filipina (Dewi, 2011).

Bagi masyarakat Indonesia, kelapa menjadi bagian dari kehidupannya karena semua bagian tanaman dapat dimanfaatkan untuk memenuhi kebutuhan ekonomi, social, dan budaya. Disamping itu, arti penting kelapa bagi masyarakat juga tercermin dari luasnya areal perkebunan rakyat yang mencapai $98 \%$ dari 3,74 juta hektar dan melibatkan lebih dari 3 juta rumah tangga petani. Pengusahaan kelapa juga membuka tambahan kesempatan kerja dari kegiatan pengolahan produk turunan dan hasil samping yang sangat beragam (Dewi, 2011).

Peluang pengembangan agribisnis kelapa dengan produk bernilai ekonomi tinggi sangat besar. Alternatif produk yang dapat dikembangkan antara lain virgin coconut oil (VCO), oleochemical (OC), desiccated coconut (DC), coconut milk/cream (CM/CC), coconut carcoal (CCL), activated carbon (AC), brown sugar (BS), coconut fiber (CF), coconut wood (CW), yang diusahakan secara parsial maupun

Agrisosioekonomi: 
terpadu. Pelaku agribisnis produk-produk tersebut mampu meningkatakan pendapatanya 5-10 kali dibandingkan dengan bila hanya menjual produk kopra (Allorerung dkk dalam Basmar, 2008).

\section{Konsep Dasar Pedagang dan Pedagang pengumpul}

Pedagang adalah orang yang berusaha di bidang produksi dan penjualan barang-barang atau jasa-jasa untuk memenuhi kebutuhan di dalam masyarakat, usaha tersebut dilaksanakan pada tempat-tempat yang dianggap strategis dalam suasana lingkungan yang mendukung.

Sutojo (2003) membagi pedagang menjadi dua golongan, yaitu :

1. Pedagang distributor (merchant middlemen)

2. Pedagang Perantara (agent middlemen)

Pedagang pengumpul adalah badan atau orang pribadi yang kegiatan usahanya mengumpulkan hasil kehutanan, perkebunan, pertanian, danperikanan dan menjual hasil-hasil tersebut kepada badan usaha industri dan/atau eksportir yang bergerak dalam sektor kehutanan, perkebunan, pertanian dan perikanan (DJPKK, 2012).

\section{Konsep Biaya}

Menurut Supriyono (2000), biaya adalah harga perolehan yang digunakan dalam memperoleh penghasilan atau revenue yang akan dipakai sebagai pengurangan penghasilan. Simamora (2000) menyatakan bahwa biaya adalah kas atau nilai kas yang digunakan untuk barang atau jasa yang diharapkan memberi manfaat saat ini atau dimasa mendatang bagi organisasi.

Wilson (2007) mengemukakan bahwa, biaya merupakan seluruh sumber daya yang digunakan untuk menghasilkan dan memperoleh suatu barang atau jasa. Biaya dapat diklasifikasikan ke dalam biaya internal dan biaya eksternal. Biaya internal adalah biaya yang dikeluarkan dalam kegiatan proses produksi suatu barang atau jasa. Sedangkan biaya eksternal adalah biaya yang ditanggug oleh masyarakat secara tidak langsung akibat kegiatan produksi suatu kegiatan usaha. Konsep biaya dapat dirumuskan sebagai berikut :

$$
\mathbf{T C}=\mathbf{F C}+\mathbf{V C}
$$

Dimana :

$\mathrm{TC}=$ Biaya Total $($ Total cost $)$

$\mathrm{FC}=$ Biaya Tetap (Fixed cost $)$

$\mathrm{VC}=$ Biaya Variabel (Variable cost)

\section{Konsep Harga}

Anoraga (2000) menyatakan bahwa, harga adalah variabel yang dapat dikendalikan dan dapat menentukan diterima tidaknya suatu produk oleh konsumen. Murah atau mahalnya suatu produk sangat relatif sifatnya. Harga yaitu sejumlah kompenasi baik yang berupa uang maupun barang yang dibutuhkan untuk mendapatkan sejumlah kombinasi barang dan jasa (Fuad dkk 2006).

Selanjutnya, menurut Kotler dan Keller (2012) harga adalah jumlah uang yang harus dibayar pelanggan untuk produk itu. Kebijakan mengenai harga sifatnya hanya sementara, berarti produsen harus mengikuti perkembangan harga di pasar dan harus mengetahui posisi perusahaan dalam situasi pasar secara keseluruhan.

Sebagai salah satu elemen bauran pemasaran, harga membutuhkan pertimbangan cermat yaitu :

1) Harga merupakan penyataan nilai dari suatu produk (a statement of value). Nilai adalah rasio atau perbandingan antara persepsi terhadap manfaat (perceived benefits) dengan biaya-biaya yang dikeluarkan untuk mendapatkan produk.

2) Harga merupakan aspek yang tampak jelas (visible) bagi para pembeli. Tidak jarang harga dijadikan semacam indikator kualitas jasa.

3) Harga adalah determinan untuk permintaan. Berdasarkan hukum permintaan (the law of demand), besar kecilnya harga mempengaruhi kualitas produk yang dibeli oleh konsumen. Semakin mahal harga, semakin sedikit jumlah permintaan atas produk yang bersangkutan dan sebaliknya

4) Harga berkaitan langsung dengan pendapatan dan laba. Harga adalah suatu unsur bauran pemasaran yang mendatangkan pemasukan bagi perusahaan, yang pada gilirannya berpengaruh pada besar kecilnya laba dan pangsa pasar yang diperoleh. 
5) Harga bersifat fleksibel, artinya bisa disesuaikan dengan cepat. Dari empat unsur bauran pemasaran tradisional, harga adalah elemen yang paling mudah diubah dan diadaptasikan dengan dinamika pasar.

6) Harga mempengaruhi citra dan positioning. Harga yang mahal dipersepsikan mencerminkan kualitas yang tinggi dan sebaliknya.

7) Harga merupakan masalah nomor satu yang dihadapi para manajer. Sebaliknya ini ditunjukan oleh empat level konflik potensial menyangkut aspek harga :
a. Konflik internal perusahaan
b. Konflik dalam saluran distribusi
c. Konflik dengan pesaing
d. Konflik dengan lembaga pemerintahan dan kebijakan publik

\section{Penerimaan}

Penerimaan (revenue) adalah penerimaan produsen dari hasil penjualan outputnya. Terdapat tiga konsep penting tentang penerimaan yaitu :

1) Total Revenue (TR) yaitu total penerimaan produsen dari hasil penjualan outputnya.

2) Average Revenue (AR) yaitu penerimaan produsen per unit output yang dijual.

3) Marginal Revenue (MR) kenaikan Total Revenue yang disebabkan oleh tambahan penjualan satu unit output.

Menurut Suratiyah (2009) penerimaan merupakan perkalian antara jumlah produksi yang dihasilkaan dengan harga jual produk. Soekartawi (2002) menyatakan bahwa, total penerimaan dalam usahatani diperoleh dari produksi fisik dikalikan dengan harga produksi. Bila keadaan memungkinkan, maka sebaiknya petani mengolah sendiri hasil pertaniannya untuk mendapatkan kualitas hasil yang baik yang harganya relatif tinggi dan akhirnya juga akan mendapatkan keuntungan. Secara sistematis jumlah penerimaan dapat dituliskan sebagai berikut :

$$
\mathbf{T R}=\mathbf{P Y} \times \mathbf{Y}
$$

Dimana :

TR = Total penerimaan

PY = Harga Produksi

$\mathrm{Y}=$ Jumlah Produksi

\section{Konsep Keuntungan}

Keuntungan merupakan kegiatan pedagang yang mengurangkan beberapa biaya yang dikeluarkan dengan hasil penjualan yang diperoleh dikurangi dengan biaya-biaya tersebut nilainya positif maka diperoleh keuntungan/laba (Sukirno, 2005).

Soekartawi (2002) menyatakan bahwa biaya dalam banyak kenyataan dapat diklasifikasikan menjadi dua yaitu biaya tetap seperti sewa tanah, pembelian alat pertanian dan biaya tidak tetap seperti biaya yang dikeluarkan untuk membeli bibiit, pupuk, dan pembayaran tenaga kerja. Dalam menentukan keuntungan secara ekonomi memerlukan sebuah fungsi, sehingga setiap pemecahan masalah ekonomi dapat dijabarkan dengan sistematis. Total Revenue (penerimaan total) Total Cost (Biaya Total). Hal ini tak lepas dari keuntungan, yang secara matematis dapat ditulis sebagai berikut :

$$
\boldsymbol{\pi}=\mathbf{T R}-\mathbf{T C}
$$

Dimana :

$$
\begin{aligned}
& \pi \text { = Keuntungan (profit) } \\
& \text { TR }=\text { Penerimaan Total (Total Revenue) } \\
& \text { TC }=\text { Total biaya Produksi (Total Cost) }
\end{aligned}
$$

\section{Rumusan Masalah}

Rumusan masalah pada penelitian ini yaitu berapa besar keuntungan pedagang pengumpul "Kelapa Kuah" di Desa Tewasen, Kecamatan Amurang Barat.

\section{Tujuan Penelitian}

Berdasarkan latar belakang dan permasalahan yang telah dikemukakan, penelitian ini bertujuan untuk menghitung keuntungan pedagang pengumpul "Kelapa Kuah" di Desa Tewasen, Kecamatan Amurang Barat.

\section{Manfaat Penelitian}

Manfaat yang dapat diperoleh dari penelitian ini agar dapat memberikan informasi bagi pihak yang memerlukannya untuk menambah pengetahuan pedagang pengumpul mengenai usaha "Kelapa Kuah". 


\section{METODE PENELITIAN}

\section{Waktu dan Temat Penelitian}

Penelititan dilaksanakan di Desa Tewasen Kecamatan Amurang Barat Kabupaten Minahasa Selatan selama 3 bulan dari bulan April sampai Juni tahun 2018.

\section{Metode Pengumpulan Data}

Penelitian ini menggunakan metode survey, data yang diambil yaitu data primer dan sekunder. Data primer yaitu data yang diperoleh dari wawancara langsung kepada pedagang pengumpul "Kelapa Kuah" menggunakan daftar pertanyaan. Sedangkan data sekunder diperoleh dari Badan Pusat statistik (BPS), Direktorat Jendral Perkebunan, internet, dan sumber-sumber lain yang memiliki relevansi dalam penelitian ini.

\section{Konsep Pengukuran Variabel}

Variabel yang akan di ukur dalam penelitian ini adalah :

1. Harga Beli adalah Harga pembelian kelapa pada petani oleh pedagang pengumpul dinyatakan dalam satuan $\mathrm{Rp} / \mathrm{kg}$ pada periode bulan April sampai Juni

2. Harga jual adalah harga penjualan kelapa pada perusahaan tepung kelapa yang dinyatakan dalam satuan $\mathrm{Rp} / \mathrm{kg}$ pada periode bulan April sampai bulan Juni

3. Volume pembelian adalah jumlah pembelian kelapa pada petani dinyatakan dalam satuan kilogram dalam periode bulan April sampai bulan Juni

4. Volume penjualan adalah jumlah penjualan kelapa pada perusahaan tepung kelapa dinyatakan dalam satuan kilogram pada priode bulan April sampai bulan Juni

5. Biaya adalah yaitu besarnya biaya yang dikeluarkan dalam usaha jual beli "Kelapa Kuah".
a) Biaya Tetap
- Penyusutan alat; yang dihitung dengan straight line method:
Biaya penyusutan $=$ Harga beli - Nilai sisa Umur ekonomis
b) Biaya Variabel
- Biaya pembelian kelapa
- Biaya tenaga kerja

\section{Analisis Data}

Data yang terkumpulakan dianalisis menggunakan analisis keuntungan dengan menghitung selisih antara penerimaan dengan biaya yang digunakan. Data yang dikumpulkan akandisajikan dalam bentuk tabel dan dianalisis secara deskriptif kemudian akan diukur dengan Analisis Keuntungan dan Analisis Revenue Cost Ratio (R/C).

Untuk mengukur keuntungan yang menjadi tujuan pertama, digunakan rumusrumus sebagai berikut :

1. Rumus Keuntungan

Dimana :

$$
\pi=\mathbf{T R}-\mathbf{T C}
$$

$\pi=$ Keuntungan (Profit)

$\mathrm{TR}=$ Penerimaan Total (Total Revenue)

$\mathrm{TC}=$ Total Biaya (Total Cost)

2. Rumus Penerimaan

$$
\mathbf{T R}=\mathbf{P Y} \times \mathbf{Y}
$$

Dimana :

$\mathrm{TR}=$ Total penerimaan

PY $=$ Harga Produksi

$\mathrm{Y}=$ Jumlah Produksi

3. Rumus Biaya

\begin{tabular}{|l|}
\hline TC $=\mathbf{F C}+\mathbf{V C}$ \\
Dimana $:$ \\
TC = Biaya Total $($ Total Cost $)$ \\
FC = Biaya Tetap $($ Fixed Cost $)$ \\
VC =Biaya Variabel (Variabel Cost $)$
\end{tabular}

Kemudian untuk mengetahui apakah usaha jual beli kelapa ini menguntungkan atau tidak dapat digunakan rumus :

$\mathbf{a}=\mathbf{R} / \mathbf{C}$

$=(\mathbf{P y} . \mathbf{Y}) /(\mathbf{F C}+\mathrm{VC})$ 
Dimana :

$\mathrm{a}=$ Revenue Cost Ratio

$\mathrm{R}=$ Revenue / Penerimaan

$\mathrm{C}=$ Cost / Biaya

$\mathrm{Py}=$ Output Price / Harga Jual

$\mathrm{Y}=$ Output / Volume Jual

$\mathrm{FC}=$ Fixed Cost $/$ Biaya Tetap

Apabila :

$\mathrm{R} / \mathrm{C}=1$, berarti usaha ini tidak untung atau rugi

$\mathrm{R} / \mathrm{C}<1$, berarti usaha ini rugi

$\mathrm{R} / \mathrm{C}>1$, berarti usaha untung

\section{HASIL DAN PEMBAHASAN}

\section{Deskripsi Daerah Penelitian}

\section{Letak Geografis dan Luas wilayah}

Desa Tewasen adalah sebuah desa yang terletak di wilayah Kecamatan Amurang Barat, Kabupaten Minahasa Selatan, Provinsi Sulawesi Utara yang terdiri dari delapan jaga dengan batas wilayah :

Sebelah Utara : Kelurahan Rumoong Bawah Sebelah Selatan : Desa Pondos

SebelahBarat : Desa Teep, Desa Tawaang

Sebelah Timur : Desa Elusan

Luas wilayah desa Tewasen adalah 2.100 Ha sedangkan luas pemukiman desa Tewasen $16 \mathrm{Ha}$. Desa ini berjarak $80 \mathrm{Km}$ dari Ibukota Provinsi (Manado).

\section{Jumlah Penduduk}

Desa Tewasen memiliki 454 KK dengan jumlah penduduk sebanyak 1425 jiwa yang tersebar dalam 8 jaga. Jumlah penduduk laki-laki sebanyak 713 jiwa sedangkan jumlah penduduk perempuan 712 jiwa.

\section{Mata Pencarian}

Tingkat perekonomian Desa Tewasen umumnya ditentukan oleh sektor pertanian. Mata pencarian terbesar adalah sebagai petani yaitu $95 \%$ dan sisanya $5 \%$ jenis pekerjaan lainnya seperti pegawai negeri sipil, swasta, pedagang dan peternak. Kelapa adalah komoditas yang paling banyak diusahakan oleh petani di Desa Tewasen, sehingga hampir semua penduduk menjadi petani kelapa.

\section{Karakteristik Pedagang Pengumpul "Kelapa Kuah"}

Karakteristik responden pedagang pengumpul dilihat dari umur yang merupakan faktor yang dapat mempengaruhi kemampuan seseorang dalam bekerja, kemudian tingkat pendidikan yang sangat berpengaruh terhadap daya nalar dan pola pikir serta sikap dan perilaku pedagang serta pengalaman berdagang, dan jumlah tanggungan, sebagaimana tampak pada Tabel 3 .

Tabel 3 menunjukkan bahwa usia pedagang pengumpul berada pada usia yang produktif untuk bekerja, karena berada pada rentang umur 18-65 tahun. Semakin tua umur seseorang setelah melewati batas umur tertentu maka semakin berkurang kemampuan untuk bekerja. Tingkat pendidikan berada pada tingkat menengah sehingga dapat memberikan variasi dalam berpikir, bersikap dan bertindak dalam mengambil keputusan serta menentukan tingkat laba dan rugi demi kelancaran usaha yang sedang dan sementara dilakukan. Pengalaman berdagang pedagang pengumpul kelapa selama 17 tahun sudah dapat mempengaruhi cara dan keahlian berdagang kelapa, yaitu menentukan volume penjualan, kerjasama antar petani dan pedagang, serta kecepatan memperoleh informasi seperti penurunan dan kenaikan harga "Kelapa Kuah" dari perusahaan tepung kelapa. Jumlah tanggungan pedagang pengumpul hanya 1 orang.

Tabel 3. Karakteristik Pedagang Pengumpul "Kelapa Kuah"

\begin{tabular}{llr}
\hline No & Karakteristik Pedagang & Keterangan \\
\hline 1. & Umur & 48 tahun \\
2. & Tingkat pendidikan & SMA \\
3. & Pengalaman berdagang & 17 tahun \\
4. & Jumlah tanggungan & 1 orang \\
\hline \multicolumn{2}{l}{ Sumber : Data Primer yang diolah, 2018 }
\end{tabular}

\section{Pemasaran "Kelapa Kuah" di Desa Tewasen}

Awal pemasaran "Kelapa Kuah" di desa Tewasen dilakukan petani setelah kelapa dipanjat, dikupas, kemudian dikumpul dan diangkut oleh petani menggunakan roda sapi atau sepeda motor dari kebun untuk dibawa kepada pedagang pengumpul. Kadang-kadang petani menghubungi pedagang pengumpul untuk mengangkut kelapanya menggunakan kendaraan roda empat (pickup) yang dimiliki oleh pedagang pengumpul. 
Sistem penjualan "Kelapa Kuah" di desa Tewasen yaitu dari petani menjual kelapa ke pedagang pengumpul lalu dari pengumpul dijual kepada perusahaan tepung kelapa PT Tri Mustika Cocominaesa. Selain itu, ada juga petani yang mengolah kelapa menjadi kopra untuk kemudian dijual ke pedagang pengumpul dan dari pedagang pengumpul menjual ke perusahaan kopra PT Cargil.

Perusahaan tepung kelapa yang menentukan harga pada pedagang pengumpul, kemudian pedagang pengumpul yang menetapkan harga pada petani dengan mempertimbangkan tingkat keuntungan untuk mendapatkan keuntungan yang diharapkan-nya. Naik turunnya harga "Kelapa Kuah" mengikuti banyaknya stok yang dimiliki perusahaan, ketika stok perusahaan banyak maka harga "Kelapa Kuah" turun dan sebaliknya, jika stok perusahaan sedikit maka harga "Kelapa Kuah" meningkat.

\section{Lembaga Pemasaran Kelapa}

Sistem pemasaran kelapa di Desa Tewasen tidak lepas dari peran lembaga pemasaran yang mengambil bagian dalam kegiatan pemasaran. Lembaga pemasaran terdiri dari petani, pedagang pengumpul, dan perusahaan kelapa yang masing-masing Lembaga pemasaran memiliki peranan penting dalam pemasaran kelapa.

1) Petani

Petani merupakan produsen kelapa yang mengawali pemasaran kelapa, petani menjual kelapa yang telah dipanjat dan dikupas sabutnya kepada pedagang pengumpul kelapa.

2) Pedagang Pengumpul

Pedagang yang membeli "Kelapa Kuah" untuk kemudian dijual kepada perusahaan kelapa. Hasil penelitian menunjukkan bahwa hanya terdapat 1 pedagang pengumpul yang berada di Desa Tewasen yang membeli "Kelapa Kuah" kepada petani untuk kemudian di distribusikan ke perusahaan tepung kelapa. Pedagang pengumpul sudah menjadi distributor tetap perusahaan tepung kelapa (supplier).
3) Perusahaan Tepung Kelapa

Perusahan yang membeli kelapa kepada pedagang pengumpul yang kemudian kelapa diolah menjadi tepung kelapa untuk di ekspor ke luar negeri. Perusahaan tersebut adalah PT Trimustika Coco Minaesa.

\section{Saluran Pemasaran Kelapa di Desa Tewasen}

Saluran pemasaran kelapa adalah rangkaian lembaga-lembaga pemasaran yang dilalui dalam penyaluran "Kelapa Kuah" di Desa Tewasen dan hanya terdapat satu saluran pemasaran seperti Gambar 1 :

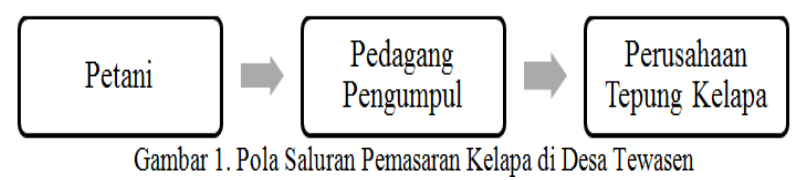

Dengan sistem ini produsen (petani) langsung menjual kelapa kepada pedagang pengumpul yang ada di Desa Tewasen yang pada umumnya sudah menjadi langganan. Umumnya pedagang pengumpul mempunyai hubungan secara emosional baik secara pertemanan ataupun hubungan keluarga dengan petani sehingga petani selalu menjual hasil panen kelapanya kepada pedagang pengumpul.

Biasanya rata-rata 3 bulan sekali petani akan memanen pohon kelapanya. Selanjutnya pedagang pengumpul biasanya akan mengangkut kelapa tersebut sebanyak 2 sampai 4 kali per minggu tergantung banyaknya kelapa yang dibeli hingga bak penampungan kelapa dari pedagang pengumpul penuh atau jumlah kelapa telah mencapai 2100 kilogram yaitu sama dengan kapasitas angkut dari kendaraan roda empat (pickup) dan siap untuk diangkut ke perusahaan.

\section{Pembelian dan Penjualan "Kelapa Kuah" Pedagang Pengumpul}

Aktivitas pembelian dan penjualan "Kelapa Kuah" dari pedagang pengumpul dapat memberikan gambaran tentang harga beli, harga jual, volume pembelian dan volume pejualan pada periode waktu penelitian yaitu bulan April, Mei, Juni tahun 2018 yang dapat dilihat pada Tabel 4. 
Tabel 4 menunjukkan aktivitas pembelian kelapa sejak bulan April hingga Juni 2018. Bulan April dan Mei memiliki harga yang lebih tinggi dibandingakan pada bulan Juni walaupun kelapa yang dibeli pedagang pengumpul cenderung lebih banyak pada bulan April dan Mei, karena stok "Kelapa Kuah" yang dimiliki perusahaan mulai menipis. Sedangkan pada bulan Juni, stok perusahaan masih relatif banyak sehingga harga yang ditetapkan perusahaan lebih rendah dari bulan April dan Mei. Akibatnya jumlah yang dijual petani ke pedagang pengumpul menurun secara signifikan. Rendahnya harga beli pada pedagang pengumpul menyebabkan sebagian petani memilih mengolah kelapanya menjadi kopra dari pada menjual kepada pedagang pengumpul. Penentuan harga dari "Kelapa Kuah" yang ditentukan oleh perusahaan secara sepihak karena struktur pasar "Kelapa Kuah" di Desa Tewasen adalah struktur pasar yang monopsoni.

Tabel 4. Pembelian dan Penjualan Kelapa Pedagang Pengumpul "Kelapa Kuah" bulan April, Mei, Juni 2018

\begin{tabular}{lrrr}
\hline \multicolumn{1}{c}{ Uraian } & \multicolumn{3}{c}{ Bulan } \\
\hline April & Mei & Juni \\
\hline Harga Beli & Rp.1300 & Rp.1300 & Rp.1200 \\
Harga Jual & Rp.1550 & Rp.1550 & Rp.1450 \\
Volume Pembelian & 25 Ton & 28 Ton & 19 Ton \\
Volume Penjualan & 25 Ton & 28 Ton & 19 Ton \\
\hline \multicolumn{3}{l}{ Sumber : Data primer yang diolah, 2018 } & \\
\end{tabular}

\section{Biaya Tetap}

Biaya tetap adalah biaya yang tidak berubah ketika usaha yang dijalankan meningkat ataupun menurun, karena tidak tergantung dari besar kecilnya volume produksi. Dalam penelitian ini biaya tetap yang dihitung adalah biaya penyusutan alat yang dapat dilihat pada Tabel 5. Penyusutan alat terbesar terdapat pada alat timbangan, diikuti dengan bak penampung, keranjang dan kalkulator.

\begin{tabular}{|c|c|c|c|c|c|c|c|}
\hline$\Phi_{0}$ & Jenis Baring & Jh & Harga Beti( $\left(R_{p}\right)$ & IVliki:Imal (Rp) & Lilai Sisa (RR) & Tmur Elkonomis & Silla perrusutan (Re) \\
\hline 1 & Iimbangan & 1 & 2750000 & 2.750 .000 & 40.000 & 36 & 2258831 \\
\hline 2 & Reraizing & 2 & 150000 & 150000 & 0 & 8 & 56250 \\
\hline 3 & Rellolidor & 1 & 40.000 & 40.000 & 0 & 16 & 75.000 \\
\hline 4 & Batipenamping & 1 & 1.090 .000 & 1.090 .000 & 0 & 40 & 81.750 \\
\hline & Total & & & & & & 4388.831 \\
\hline
\end{tabular}

\section{Biaya Variabel}

Biaya variabel adalah biaya yang tidak tetap dan akan berubah ketika kapasitas yang digunakan semakin besar maka semakin besar pula total biaya variabelnya. Biaya varibel pedagang pengumpul "Kelapa Kuah" dapat dilihat pada Tabel 6. Biaya ini adalah biaya yang digunakan pedagang pengumpul untuk membeli "Kelapa Kuah" pada petani dengan harga yang sudah di tetapkan dari bulan April, Mei, Juni 2018 sebanyak 72 ton. Biaya angkut "Kelapa Kuah" ditanggung sepenuhnya oleh perusahaan.

Tabel 6. Biaya Variabel Pedagang Pengumpul "Kelapa Kuah" Bulan April, Mei, Juni 2018

\begin{tabular}{|c|c|c|c|}
\hline No & Jenis Biaya & Bulan & Jumlah \\
\hline \multirow[t]{3}{*}{1} & Biaya Pembelian Kelapa & April & 32.500 .000 \\
\hline & & Mei & 36.400 .000 \\
\hline & & Juni & 22.800 .000 \\
\hline \multirow[t]{4}{*}{2} & Biaya Tenaga Kerja & April & 240.000 \\
\hline & & Mei & 280.000 \\
\hline & & Juni & 180.000 \\
\hline & Total & & 92.400 .000 \\
\hline
\end{tabular}

Sumber : Data Primer yang diolah, 2018

\section{Penerimaan}

Penerimaan Pedagang Pengumpul adalah perkalian antara produksi jumlah kelapa yang dibeli dengan harga jual "Kelapa Kuah". Penerimaan pedagang pengumpul "Kelapa Kuah" pada bulan April, Mei Juni 2018 dapat di lihat pada Tabel 7. Penerimaan terbesar pada bulan Mei sebanyak 43.400.000,- dan terkecil bulan Juni sebanyak 27.550.000,-. Hal ini disebabkan karena masih banyaknya stok kelapa diperusahaan tepung kelapa sehingga perusahaan menurunkan harga kelapa, dan sebagai akibat dari harga yang turun maka sebagian petani mengolah kelapanya menjadi kopra daripada menjual dalam bentuk "Kelapa Kuah".

Tabel 7. Penerimaan Pedagang Pengumpul "Kelapa Kuah" bulan April, Mei, Juni 2018

\begin{tabular}{clrrr}
\hline No & Bulan & Jumlah & Harga/Kg & Penerimaan \\
\hline 1 & April & 25 Ton & 1550 & 38.750 .000 \\
2 & Mei & 28 Ton & 1550 & 43.400 .000 \\
3 & Juni & 19 Ton & 1450 & 27.550 .000 \\
\hline & Total & 72 Ton & & 109.700 .000 \\
\hline
\end{tabular}

Sumber : Data Primer yang diolah, 2018

\section{Keuntungan}

Untuk mengetahui berapa besar keuntungan yang diperoleh pedagang pengumpul "Kelapa Kuah" maka akan dilakukan analisis keuntungan yaitu pengurangan antara penerimaan dengan semua biaya yang di keluarkannya. Keuntungan 
pedagang pengumpul "Kelapa Kuah" bulan April, Mei, Juni 2018 dapat dillihat pada Tabel 8. Jadi keuntungan yang diperoleh Pedagang Pengumpul "Kelapa Kuah" di Desa Tewasen periode bulan April - Juni 2018 yaitu sebesar Rp. 16.861.169,--

Tabel 8. Keuntungan Pedagang Pengumpul "Kelapa Kuah" bulan April, Mei, Juni 2018

\begin{tabular}{lr}
\multicolumn{2}{c}{ bulan April, Mei, Juni 2018 } \\
\hline Penerimaan & Jumlah \\
Biaya Tetap & 438.700 .000 \\
Biaya Variabel & 92.400 .000 \\
Total Biaya & 92.838 .831 \\
Keuntungan & 16.861 .169 \\
\hline Sumber : Data Primer yang diolah, 2018
\end{tabular}

\section{Analisis Revenue Cost Ratio (R/C)}

Tingkat keuntungan ekonomi dapat diketahui dengan menggunakan analisis Revenue Cost Ratio ( $\mathrm{R} / \mathrm{C}$ ratio) yang adalah perbandingan antara penerimaan dan biaya. Ratio yang menjadi parameternya adalah nilai $\mathrm{R} / \mathrm{C}=1$ berarti usaha tidak untung dan tidak rugi, nilai $\mathrm{R} / \mathrm{C} \geq 1$ berarti usaha untung, nilai $\mathrm{R} / \mathrm{C} \leq 1$ berarti usaha rugi, dapat dilihat pada Tabel 9.

Tabel 9 menunjukkan bahwa nilai $\mathrm{R} / \mathrm{C}$ ratio sebesar 1,18 . Nilai $\mathrm{R} / \mathrm{C}$ lebih dari satu berarti usaha pedagang pengumpul "Kelapa Kuah" di Desa Tewasen menguntungkan secara ekonomi dan dapat terus dipertahankan.

Tabel 9. R/C Ratio Pedagang Pengumpul "Kelapa Kuah" di Desa Tewasen Kecamatan Amurang Barat

\begin{tabular}{clr}
\hline No & \multicolumn{1}{c}{ Keterangan } & Jumlah \\
\hline 1 & Penerimaan (Revenue) & 109.700 .000 \\
2 & Biaya (Cost) & 92.496 .527 \\
3 & R/C Ratio & 1,18 \\
\hline \multicolumn{2}{l}{ Sumber : Data Primer yang diolah, 2018 }
\end{tabular}

\section{KESIMPULAN DAN SARAN}

\section{Kesimpulan}

Usaha jual beli "Kelapa Kuah" di Desa Tewasen Kecamatan Amurang Barat mampu memberikan keuntungan kepada pedagang pengumpul. Kentungan pedagang pengumpul "Kelapa Kuah" pada periode bulan April hingga juni 2018 sebesar Rp. 16.861.169.

\section{Saran}

Usaha jual-beli pedagang pengumpul "Kelapa Kuah" di Desa Tewasen memberikan keuntungan, oleh sebab itu pedagang pengumpul dapat membeli "Kelapa Kuah" dalam jumlah yang banyak sehingga memiliki keuntungan yang lebih besar pula.

\section{DAFTAR PUSTAKA}

Anoraga, P. 2000. Manajemen Bisnis. Jakarta: Rineka Cipta.

Basmar, A. 2008. Arahan Pengembangan Usaha Kawasan Agro Terpadu Berbasis Komoditas Kelapa di Kabupaten Lampung Barat. Sekolah Pasca Sarjana Institut Pertanian Bogor.

Dewi, A. P. 2011. Strategi Pemasaran Produk Agroindustri Kelapa Berorientasi Ekspor.Skripsi. Fakultas Teknologi Pertanian. Institut Pertanian Bogor.

Dongi, R. 2014 Perbandingan Tingkat Petani Kentang dilihat dari Saluran Pemasaran yang Berasal dari Desa Makaaruyen Kecamatan Modoinding.

Fuad, M, dkk. 2006. Pengantar Bisnis. Cetakan Kelima. Jakarta : PT Gramedia Pustaka Umum.

Kotler dan Keller. (2012). Manajemen Pemasaran. Edisi 12. Jakarta : Erlangga.

Samsul, 2017. Analisis Biaya dan Pendapatan Usaha Pemasaran Kelapa Muda di kota Kendari.

Soekartawi. 2002. "Teori Ekonomi Pertanian". PT. Raja Grafindo Persada. Jakarta.

Sukirno, S. 2005. Mikro Ekonomi Teori Pengantar, Edisi Ketiga, Raja Gafindo Persada.

Supriyono, R. A, 2000. Akuntansi Biaya : Perencanaan dan Pengendalian Biaya Serta Pembuatan Keputusan, Edisi kedua BPFE. Yogyakarta.

Suratiyah, 2009. Ilmu Usahatani. UI Press. Jakarta.

Simamora, 2000. Akuntansi: Basis Pengambilan Keputusan Bisnis, Jilid Satu. Salemba Empat. Jakarta.

Wilson. 2007. Teori dan Analisi Biaya. Penerbit Grafindo. Jakarta. 